\title{
Biological control of tomato bacterial spot by saprobe fungi from semi-arid areas of northeastern Brazil
}

\section{Controle biológico da mancha bacteriana do tomateiro usando fungos sapróbios do semiárido nordestino do Brasil}

\author{
Douglas Casaroto Peitl ${ }^{1}$; Felipe Andre Araujo ${ }^{2}$; Ricardo Marcelo Gonçalves ${ }^{3}$; \\ Débora Cristina Santiago ${ }^{4}$; Ciro Hideki Sumida ${ }^{4}$; Maria Isabel Balbi-Peña ${ }^{4 *}$
}

\begin{abstract}
Tomato bacterial spot caused by Xanthomonas spp., is a common disease in tomato fields that causes significant economic losses. Due to the difficulty with control of bacterial spot by conventional methods, new techniques such as biological control and induction of resistance are gaining prominence. This study aimed to select saprobe fungi from semi-arid regions of the Brazilian Northeast for the biological control of bacterial spot of tomato. To select the best isolates to control bacterial spot, a greenhouse experiment was initially conducted. Tomato plants ('Santa Cruz Kada') were treated with filtrates of 25 saprobe fungi and inoculated three days later with Xanthomonas euvesicatoria. Filtrates of Memnoniella levispora, Periconia hispidula, Zygosporium echinosporum, and Chloridium virescens var. virescens were selected as the most effective. Filtrates and volatile compounds from these four isolates were tested for their antibacterial activity in cultures of $X$. euvesicatoria and in tomato plants ('Santa Cruz Kada') inoculated with $X$. euvesicatoria. In vitro, the addition of nonvolatile fungal metabolites into the culture medium at $5 \%$ and $50 \%(\mathrm{v} / \mathrm{v})$ inhibited bacterial growth by $28.9 \%$ and $53.8 \%$, respectively. The volatile compounds produced by $C$. virescens var. virescens reduced the number of colony-forming units of $X$. euvesicatoria by $25.9 \%$. In vivo, all treatments reduced from 62.4 to $71.3 \%$ the area under bacterial spot progress curve, showing the same control efficacy as the commercial resistance inducer used as a positive control (acibenzolar-S-methyl). Systemicity of the fungal filtrates was confirmed in a separate experiment, where application of the treatments exclusively to the third leaf decreased the severity of the disease on the fourth leaf (except for $C$. virescens var. virescens). These results show that M. levispora, P. hispidula, Z. echinosporum, and C. virescens var. virescens are potential biocontrol agents against tomato bacterial spot. Further studies are necessary to elucidate the disease control mechanisms of these saprobe fungi.
\end{abstract}

Key words: Acibenzolar-S-methyl. Antibiosis. Fungal metabolite. Xanthomonas euvesicatoria.

\section{Resumo}

A mancha bacteriana do tomateiro causada por Xanthomonas spp. é uma doença frequente nos campos de cultivo, provocando importantes perdas econômicas. Devido à dificuldade de controle com os métodos tradicionais, novas ferramentas de manejo para esta doença, como o controle biológico e a indução de resistência vêm ganhando destaque. O objetivo desse trabalho foi a seleção de fungos sapróbios do semiárido nordestino brasileiro para o controle biológico da mancha bacteriana do tomateiro.

\footnotetext{
${ }^{1}$ Me., Programa de Pós-Graduação em Agronomia, Universidade Estadual de Londrina, UEL, PR, Brasil. E-mail: douglaspeitl@ gmail.com

2 Discente curso de Mestrado, Programa de Pós-Graduação em Agronomia, UEL, PR, Brasil. E-mail: araujo.felipe.a@hotmail.com

3 Pós-Doutorando, Programa de Pós-Graduação em Agronomia, UEL, PR, Brasil. E-mail: rmgoncalves@icloud.com

${ }^{4}$ Profs. Drs., Departamento de Agronomia, UEL, PR, Brasil. E-mail: santiago@uel.br; cirosumida@hotmail.com; mariabalbi@ uel.br

* Author for correspondence
} 
Inicialmente, com o objetivo de selecionar os isolados que apresentassem melhor controle da mancha bacteriana, foi montado um ensaio em casa de vegetação com tomateiros ('Santa Cruz Kada') tratados com os filtrados de 25 fungos sapróbios e inoculados com a bactéria Xanthomonas euvesicatoria três dias depois. Foram selecionados os isolados de Memnoniella levispora, Periconia hispidula, Zygosporium echinosporum e Chloridium virescens var. virescens. Filtrados e voláteis fúngicos desses quatro isolados foram testados in vitro, para se determinar a sensibilidade da bactéria fitopatogênica, e in vivo em tomateiros ('Santa Cruz Kada') tratados e inoculados com $X$. euvesicatoria. A incorporação de metabólitos não voláteis dos fungos no meio de cultura a $5 \%$ e $50 \%(\mathrm{v} / \mathrm{v})$ controlou o crescimento da bactéria em até $28,9 \%$ e $53,8 \%$, respectivamente. Os compostos voláteis produzidos por $C$. virescens var. virescens inibiram até $25,9 \%$ das unidades formadoras de colônias. Com relação ao experimento in vivo, todos os tratamentos testados reduziram de 62,4 a $71,3 \%$ a área abaixo da curva de progresso da mancha bacteriana, mostrando nível de controle igual ao indutor de resistência comercial utilizado como controle positivo (acibenzolar-S-metílico). A sistemicidade deste controle foi confirmada em outro experimento, onde a aplicação dos tratamentos somente na terceira folha determinou menor severidade da doença na quarta folha (exceto para $C$. virescens var. virescens). Conclui-se que $M$. levispora, $P$. hispidula, Z. echinosporum e C. virescens var. virescens apresentaram potencial de biocontrole da mancha bacteriana do tomateiro. Estudos futuros são necessários para elucidar a natureza do controle da doença exercido por estes fungos sapróbios.

Palavras-chave: Acibenzolar-S-metílico. Antibiose. Metabólitos fúngicos. Xanthomonas euvesicatoria.

\section{Introduction}

Tomato (Solanum lycopersicum L.) is the most commonly cultivated vegetable in Brazil (IBGE, 2013). The national production in 2013 was 4.19 million tons in a total area of 66.8 thousand hectares (FAO, 2016). The cultivation is affected by several diseases including bacterial spot, which can be caused by Xanthomonas vesicatoria, X. euvesicatoria, X. perforans, or X. gardneri (JONES et al., 2004). In Brazil, the most frequent causative agent of bacterial spot in tomato is $X$. perforans (ARAÚJO et al., 2017), whereas $X$. euvesicatoria is the predominant species in bell pepper crops (AREAS et al., 2015). Bacterial spot is a severe disease that can affect the leaves, fruits, flowers, and stems of tomato plants and ultimately cause the loss of these organs (BYRNE et al., 2005; LOPES; ÁVILA, 2005). In addition to production losses, the disease also causes fruit depreciation due to disease lesions and sun scalding associated with defoliation caused by the disease (BYRNE et al., 2005).

Conventional control methods for bacterial spot include crop rotation, the use of certified healthy seeds, uncontaminated transplants, adequate disposal of crop residues, and application of cupric bactericides (BYRNE et al., 2005). Although the use of resistant varieties is an efficient practice for disease control, tomato bacterial spot resistance is difficult to obtain and can be overcome by the pathogenic bacteria over time (JONES et al., 1998; RITCHIE, 2007). The chemical control of bacterial spot by the application of cupric bactericides alone or in combination with the fungicide mancozeb, is currently the most popular method among the growers of commercial tomato crops. However, under environmental conditions favorable to the development of the disease (high temperatures, rainfall, and especially rainfall with wind), chemical control methods have been shown to be ineffective (PERNEZNY et al., 2012). In addition, cupric bactericides have lost efficacy for the control of bacterial spot because of the emergence of copper-resistant isolates (MARTIN et al., 2004). These chemicals may persist at sites beyond the target, such as the soil and water, with residence time varying according to chemical properties (soil adsorption capacity and degradation susceptibility) and environmental factors (soil type, rainfall, topography, and agricultural practices). Furthermore, they may have adverse effects, including toxicity to beneficial soil microorganisms, fish, and aquatic invertebrates (WIGHTWICK et al., 2010). There is a need for new bactericidal products for plant 
disease control with low toxicity to humans and to the environment.

Chemical compounds that activate plant defenses, which are termed systemic acquired resistance (SAR) inducers, such as acibenzolar$S$-methyl (ASM), have shown bacterial spot control efficacies comparable to those of cupric bactericide and mancozeb treatments (PERNEZNY et al., 2012). Biological control methods using bacteriophages specific for $X$. vesicatoria strains (FLAHERTY et al., 2000; OBRADOVIC et al., 2004, 2005), antagonistic bacteria applied to the phylloplane (BYRNE et al., 2005; EL-HENDAWY et al., 2005; ROBERTS et al., 2008), SAR-inducing rhizobacteria (FERRAZ et al., 2015), SARinducing endophytic bacteria (LANNA-FILHO et al., 2013), aqueous extracts containing various organic compounds (AL-DAHMANI et al., 2003), and avirulent strains that antagonize natural virulent strains (MOSS et al., 2007) have shown varying efficacies for bacterial spot control.

Saprobe fungi have desirable characteristics for use in biological control (BARROS et al., 2015) and a resistance-inducing potential (RESENDE et al., 2015; YEDIDIA et al., 2003). They can secrete pectinases, induce oligogalacturonides release; and activate the plant defense responses (BARROS et al., 2015). The use of saprobe fungi from semi-arid Brazilian caatinga ecoregion was favored due to their potential as biocontrol agents, including their ability to remove nutrients from dead tissue, resistance to water restriction, and competitiveness with other microorganisms (PINTO, 2013; RESENDE et al., 2015).

The aim of this study was to select saprobe fungi from semi-arid regions of the Brazilian Northeast for the biological control of bacterial spot of tomato.

\section{Materials and Methods}

Collection and preservation of saprobe fungi and Xanthomonas euvesicatoria isolates

Saprobe fungi were collected in the semi-arid region of the Brazilian Northeast and belong to the Collection of Cultures of Microorganisms of Bahia (CCMB), State University of Feira de Santana, BA, Brazil (CNPq process number 010044/20140 ). Twenty-five fungal isolates (Table 1) were tested. The isolates were kept at $25{ }^{\circ} \mathrm{C}$ in Petri dishes containing potato dextrose agar (PDA) culture medium (200 $\mathrm{g} \mathrm{L}^{-1}$ potato infusion, $20 \mathrm{~g} \mathrm{~L}^{-1}$ dextrose, $15 \mathrm{~g} \mathrm{~L}^{-1}$ agar, $\mathrm{pH} 5.6 \pm 0.2$ at $25^{\circ} \mathrm{C}$ ) with a photoperiod of $12 \mathrm{~h}$.

We used $X$. euvesicatoria isolate 81-23 (STALL et al., 1986). Phytobacteria was kept in nutrient agar culture medium (NA; $3 \mathrm{~g} \mathrm{~L}^{-1}$ meat extract, 5 $\mathrm{g} \mathrm{L}^{-1}$ peptone, $15 \mathrm{~g} \mathrm{~L}^{-1}$ agar, $\mathrm{pH} 6.8 \pm 0.2$ ) at 28 ${ }^{\circ} \mathrm{C}$ in darkness. The isolate was characterized by polymerase chain reaction (PCR) using primers specific for the four pathogenic bacterial species that cause bacterial spot in tomato. The bacterial DNA was extracted according to the protocol of Dellaporta et al. (1983), and the primers were designed by Koenraadt et al. (2007). The reaction conditions and thermal cycler programs matched those used by Areas et al. (2015).

\section{Preparation of fungal filtrates}

To obtain the fungal filtrates, saprobe fungi were cultured in flasks containing $100 \mathrm{~mL}$ of potato dextrose broth (PD) (200 $\mathrm{g} \mathrm{L}^{-1}$ potato infusion, $20 \mathrm{~g} \mathrm{~L}^{-1}$ dextrose, $\mathrm{pH} 5.6 \pm 0.2$ ), incubated at 25 $\pm 2{ }^{\circ} \mathrm{C}$ with a photoperiod of $12 \mathrm{~h}$ for 10 days, and then incubated at $5 \pm 2{ }^{\circ} \mathrm{C}$ for a further $48 \mathrm{~h}$. The supernatant was separated with filter paper (Whatman No. 2; Whatman, Maidstone, UK) and centrifuged twice for $15 \mathrm{~min}$ at $5000 \mathrm{rpm}$ to remove the remaining fungal structures. The supernatant was stored at $5{ }^{\circ} \mathrm{C}$. 
Table 1. Severity (percentage of affected leaf area) and area under disease progress curve (AUDPC) of bacterial spot of tomato at 7, 14, and 21 days after inoculation (DAI) with Xanthomonas euvesicatoria in plants treated with saprobe fungi filtrates. Londrina, 2015.

\begin{tabular}{|c|c|c|c|c|c|}
\hline Treatments & 7 DAI & 14 DAI & 21 DAI & AUDPC & $\begin{array}{c}\text { \% reduction } \\
\text { AUDPC }\end{array}$ \\
\hline Negative control & $15.0 \mathrm{a}^{1}$ & $23.0 \mathrm{a}$ & $52.0 \mathrm{a}$ & $22.03 \mathrm{a}$ & --- \\
\hline Phialomyces macrosporus & $6.0 \mathrm{c}$ & $21.0 \mathrm{a}$ & $50.0 \mathrm{a}$ & $18.05 \mathrm{a}$ & 18.05 \\
\hline Pseudobotrytis terrestris & $13.0 \mathrm{a}$ & $19.0 \mathrm{a}$ & $39.0 \mathrm{c}$ & $17.70 \mathrm{a}$ & 19.64 \\
\hline Clonostachys rosea & $11.0 \mathrm{~b}$ & $18.0 \mathrm{a}$ & $42.0 \mathrm{c}$ & $17.23 \mathrm{a}$ & 21.80 \\
\hline Myrothecium sp. isolate 2 & $8.0 \mathrm{c}$ & $19.0 \mathrm{a}$ & $45.0 \mathrm{~b}$ & $17.13 \mathrm{a}$ & 22.26 \\
\hline Dictyosporium tetraseriale & $9.0 \mathrm{~b}$ & $19.0 \mathrm{a}$ & $36.0 \mathrm{c}$ & $15.88 \mathrm{~b}$ & 27.93 \\
\hline Beltrania rhombica & $6.0 \mathrm{c}$ & $14.0 \mathrm{a}$ & $40.0 \mathrm{c}$ & $13.85 \mathrm{~b}$ & 37.11 \\
\hline Sarcopodium circinatum & $7.0 \mathrm{c}$ & $18.0 \mathrm{a}$ & $29.0 \mathrm{~d}$ & $13.65 \mathrm{~b}$ & 38.04 \\
\hline Thozetella submersa & $5.0 \mathrm{c}$ & $16.0 \mathrm{a}$ & $35.0 \mathrm{c}$ & $13.35 \mathrm{~b}$ & 39.38 \\
\hline Myrothecium sp. isolate 1 & $10.0 \mathrm{~b}$ & $18.0 \mathrm{a}$ & $21.0 \mathrm{e}$ & $13.23 \mathrm{~b}$ & 39.96 \\
\hline Memnoniella echinata & $5.0 \mathrm{c}$ & $14.0 \mathrm{a}$ & $38.0 \mathrm{c}$ & $13.18 \mathrm{~b}$ & 40.18 \\
\hline Dictyochaeta heteroderae & $7.0 \mathrm{c}$ & $17.0 \mathrm{a}$ & $28.0 \mathrm{~d}$ & $13.13 \mathrm{~b}$ & 40.41 \\
\hline Volutella minima & $8.0 \mathrm{c}$ & $16.0 \mathrm{a}$ & $28.0 \mathrm{~d}$ & $13.10 \mathrm{~b}$ & 40.53 \\
\hline Beltrania copaifera & $5.0 \mathrm{c}$ & $18.0 \mathrm{a}$ & $29.0 \mathrm{~d}$ & $13.00 \mathrm{~b}$ & 40.97 \\
\hline Curvularia inaequalis & $8.0 \mathrm{c}$ & $18.0 \mathrm{a}$ & $19.0 \mathrm{e}$ & $12.23 \mathrm{~b}$ & 44.50 \\
\hline Stachybotrys chartarum & $7.0 \mathrm{c}$ & $15.0 \mathrm{a}$ & $23.0 \mathrm{~d}$ & $11.55 \mathrm{c}$ & 47.56 \\
\hline Gonytrichum chlamydosporium & $6.0 \mathrm{c}$ & $16.0 \mathrm{a}$ & $21.0 \mathrm{e}$ & $11.23 \mathrm{c}$ & 49.03 \\
\hline Stachybotrys globosa & $4.0 \mathrm{c}$ & $12.0 \mathrm{~b}$ & $28.0 \mathrm{~d}$ & $10.40 \mathrm{c}$ & 52.78 \\
\hline Lappodochium lageniforme & $5.0 \mathrm{c}$ & $10.0 \mathrm{~b}$ & $27.0 \mathrm{~d}$ & $9.85 \mathrm{c}$ & 55.28 \\
\hline Curvularia eragrostidis & $5.0 \mathrm{c}$ & $8.0 \mathrm{~b}$ & $26.0 \mathrm{~d}$ & $8.98 \mathrm{c}$ & 59.25 \\
\hline Beltraniella portoricensis & $6.0 \mathrm{c}$ & $12.0 \mathrm{~b}$ & $16.0 \mathrm{f}$ & $8.95 \mathrm{c}$ & 59.37 \\
\hline Gonytrichum macrocladum & $6.0 \mathrm{c}$ & $12.0 \mathrm{~b}$ & $15.0 \mathrm{f}$ & $8.78 \mathrm{c}$ & 60.16 \\
\hline $\mathrm{ASM}^{*}$ & $5.0 \mathrm{c}$ & $12.0 \mathrm{~b}$ & $14.0 \mathrm{f}$ & $8.28 \mathrm{c}$ & 62.43 \\
\hline Periconia hispidula & $5.0 \mathrm{c}$ & $7.0 \mathrm{~b}$ & $20.0 \mathrm{e}$ & $7.58 \mathrm{c}$ & 65.60 \\
\hline Zygosporium echinosporum & $5.0 \mathrm{c}$ & $6.0 \mathrm{~b}$ & $21.0 \mathrm{e}$ & $7.40 \mathrm{c}$ & 66.39 \\
\hline CChloridium virescens var. virescens & $5.0 \mathrm{c}$ & $8.0 \mathrm{~b}$ & $15.0 \mathrm{f}$ & $7.05 \mathrm{c}$ & 68.00 \\
\hline Memnoniella levispora & $5.0 \mathrm{c}$ & $8.0 \mathrm{~b}$ & $13.0 \mathrm{f}$ & $6.70 \mathrm{c}$ & 69.58 \\
\hline C.V. $(\%)$ & 40.3 & 19.8 & 13.6 & 11.8 & \\
\hline
\end{tabular}

${ }^{1}$ Mean values followed by the same letter are not significantly different from each other according to the Scott-Knott test at 5\% probability. *Acibenzolar-S-methyl.

Screening of saprobe fungi for their ability to control bacterial spot at greenhouse conditions

The experiment was designed in randomized blocks of 27 treatments and five replicates. Tomato seedlings were grown in 180-cell trays using a commercial substrate (Tropstrato HT Hortaliças ${ }^{\circledR}$, Vida Verde, Mogi Mirim, SP, Brazil) and 'Santa Cruz Kada' cultivar. Transplanting was performed 21 days after sowing in $1-\mathrm{L}$ pots containing a mixture of soil (eutroferric red latosol) and sand in the ratio $1: 2(\mathrm{v} / \mathrm{v})$. 
The 25 isolates of saprobe fungi were individually cultured in $100 \mathrm{~mL}$ of PD medium and incubated at $25 \pm 2{ }^{\circ} \mathrm{C}$ with a photoperiod of $12 \mathrm{~h}$ for 10 days. Next, $100 \mathrm{~mL}$ of sterilized distilled water was added and the isolates were homogenized in a blender. The treatments were applied on both sides of the tomato leaves using cotton swabs. The commercial resistance inducer ASM (Bion ${ }^{\circledR}$; Syngenta Crop Protection, Inc., Greensboro, NC) was used as a positive control at a dose of $30 \mathrm{~g} \mathrm{ha}^{-1}$. Plants treated only with distilled sterilized water served as a negative control.

Bacterial inoculation was performed three days after application of the treatments. Colonies grown for $18 \mathrm{~h}$ in NA were used. The bacterial suspension was adjusted to a concentration of $10^{8}$ colony-forming units (CFU) $\mathrm{mL}^{-1}$ in saline $(0.85 \%$ $\mathrm{NaCl})$ and inoculated with sprayer. The plants were kept in a humid chamber for $48 \mathrm{~h}$ before and after the inoculation. The percentage of leaf area affected was evaluated weekly on the same leaf, according to the scale proposed by Mello et al. (1997). The area under disease progress curve (AUDPC) was calculated using the data from the three assessments. The AUDPC was calculated according to Shaner and Finney's formula (1977) and normalized by dividing the AUDPC value by the total time duration (number of days from the first occurrence of the disease until the end of the observation period) (FRY, 1978). The formula used to obtain this normalized AUDPC was as follows:

$$
\sum_{i=1}^{n} \frac{\left[\left(X_{i}+X_{i+1}\right) / 2\right]\left[t_{i+1}-t_{i}\right]}{\left(T_{n}-T_{1}\right)}
$$

where $X_{i}$ is the proportion of diseased host tissue at the $i^{\text {th }}$ evaluation, $t_{i}$ is the time in days at the $i^{\text {th }}$ evaluation, and $n$ represents the total number of observations.

The four fungal isolates with the lowest AUDPC values were selected.
In vitro effects of saprobe fungi filtrates on Xanthomonas euvesicatoria

The experimental design was completely randomized, with five replicates per treatment. Filtrates from the four selected fungi were incorporated into liquid NA medium at 5\% and 50\% $(\mathrm{v} / \mathrm{v})$ and plated. Bacterial suspension was obtained from colonies grown for $18 \mathrm{~h}$ in NA culture medium at $30{ }^{\circ} \mathrm{C}$. Next, $100-\mu \mathrm{L}$ aliquots of the bacterial suspension at the concentration of $10^{8} \mathrm{CFU} \mathrm{\textrm {mL } ^ { - 1 }}$ were spread with a Drigalski spatula on the prepared NA plates and incubated at $25 \pm 2{ }^{\circ} \mathrm{C}$ for three days, after which the number of colonies was evaluated. A negative control was prepared by the addition of PD medium.

In vitro effects of volatile compounds on Xanthomonas euvesicatoria

The experimental design was completely randomized, with five replicates per treatment. Two-sections polystyrene Petri dishes were used. PDA culture medium was placed on one side of the plate, and 5-mm diameter discs of the saprobe fungi were transferred and incubated at $25 \pm 2{ }^{\circ} \mathrm{C}$ with a photoperiod of $12 \mathrm{~h}$ for seven days. Next, NA culture medium was placed on the opposite side of the plate, and a $100-\mu \mathrm{L}$ aliquot of the bacterial suspension $\left(10^{8}\right.$ CFU $\mathrm{mL}^{-1}$ ) was dispersed with a Drigalski spatula, and incubated under the conditions described above. The bacterial colonies were evaluated after three days.

\section{Control of tomato bacterial spot by saprobe fungi in tomato plants}

The experiment was designed in randomized blocks of six treatments and five replicates. Seedlings were grown in 180-cell trays using a commercial substrate and 'Santa Cruz Kada' tomato cultivar. Transplanting was performed 21 days after sowing in 1-L pots containing a mixture of soil (eutroferric red latossol) and sand in the ratio 1:2(v/v). 
The isolates of the four selected saprobe fungi were cultured in $100 \mathrm{~mL}$ of PD medium and incubated at $25 \pm 2{ }^{\circ} \mathrm{C}$ with a photoperiod of $12 \mathrm{~h}$ for 10 days. Next, $100 \mathrm{~mL}$ of distilled sterilized water were added and the suspensions were homogenized in a blender. The treatments were applied on both sides of the tomato leaves using cotton swabs. The commercial resistance inducer ASM (30 $\left.\mathrm{g} \mathrm{ha}^{-1}\right)$ was used as a positive control and plants treated with distilled sterilized water represented the negative control.

Bacterial inoculation was performed three days after the treatments using colonies cultured for 18 $\mathrm{h}$ in NA medium. The bacterial suspension was adjusted to a concentration of $10^{8} \mathrm{CFU} \mathrm{mL}^{-1}$ in saline $(0.85 \% \mathrm{NaCl})$ and inoculated onto the plants using a sprayer. The plants were kept in a humid chamber for $48 \mathrm{~h}$ before and after inoculation. The percentage of leaf area affected was evaluated weekly on the third leaf according to the scale proposed by Mello et al. (1997). The normalized AUDPC was calculated using the data from the three evaluations.

Systemicity of bacterial spot control by saprobe fungi in tomato plants

The experiment was designed in randomized blocks of six treatments and five replicates. Filtrates of the four selected saprobe fungi isolates were used, according to the methodology described above, except that the treatment was applied exclusively on the third leaf. The severity of the disease was evaluated on the third and fourth leaves. The AUDPC was calculated using severity assessment data.

\section{Statistical analysis}

Data were subjected to analysis of variance at the 0.05 significance level. When treatments effects were significant, the means were separated by comparison tests. The Scott-Knott clustering test ( $\mathrm{p} \leq 0.05$ ) was used to compare means among treatment groups in the experiment with 25 fungi isolates, and Tukey's test ( $\mathrm{p} \leq 0.05$ ) was used to compare means among treatment groups in the experiments with four saprobe fungi.

\section{Results and Discussion}

The screening of saprobe fungi for their ability to control bacterial spot at greenhouse conditions revealed that Phialomyces macrosporus, Pseudobotrytis terrestris, Clonostachys rosea, and Myrothecium sp. isolate 2 did not significantly alter disease progress compared with the negative control (water), with AUDPC values between 17.13 and 22.03 (Table 1). Treatment with Dictyosporium tetraseriale, Beltrania rhombica, Sarcopodium circinatum, Thozetella submersa, Myrothecium sp. isolate 1, Memnoniella echinata, Dictyochaeta heteroderae, Volutella minima, B. copaifera, and Curvulariainaequalis showed statisticallysignificant intermediate control, with reductions of AUDPC ranging from 27.93 to $44.50 \%$. The most effective isolates to control bacterial spot were Stachybotrys chartarum, Gonytrichum chlamydosporium, Stachybotrys globosa, Lappodochium lageniforme, Curvularia eragrostidis, Beltraniella portoricensis, G. macrocladum, ASM, Periconia hispidula, Zygosporium echinosporum, Chloridium virescens var. virescens, and Memnoniella levispora, with reductions of AUDPC ranging from 47.56 to $69.58 \%$ (Table 1).

ASM is a commercial systemic acquired resistance (SAR) inducer, that provides the plant with protection against pathogens and causes the expression of molecular and biochemical markers in the plant, but exerts no direct action against the pathogen (KESSMANN et al., 1994). The induction of SAR to bacterial spot by ASM has been demonstrated in tomato and pepper (OBRADOVIC et al., 2005; ROBERTS et al., 2008; ROMERO et al., 2001).

P. hispidula, Z. echinosporum, C. virescens var. virescens, and $M$. levispora showed the 
highest efficacies for the control of bacterial spot in greenhouse tomato plants and they were therefore selected for additional experiments. These saprobe fungi isolates were then tested for their growth inhibitory effects on $X$. euvesicatoria. The addition of $Z$. echinosporum and $C$. virescens var. virescens filtrates to the culture medium at $5 \%$ $(\mathrm{v} / \mathrm{v})$ produced the highest inhibition of bacterial growth, with inhibition of colony-forming units of $21.9 \%$ and $28.9 \%$ (assay 1 ) and $16.0 \%$ and $27.8 \%$ (assay 2), respectively (Table 2). P. hispidula did not significantly inhibit bacterial growth compared with the negative control. The M. levispora filtrate inhibited bacterial growth by $7.0 \%$ in assay 1 , which was significantly higher than that observed for the negative control and $P$. hispidula, although this growth inhibitory effects were lower than those of the $Z$. echinosporum and $C$. virescens var. virescens treatments (Table 2).

Table 2. Inhibition of colony-forming units (CFUs per plate) of Xanthomonas euvesicatoria by addition of saprobe fungi filtrates to the bacterial culture medium at two concentrations (v/v). Londrina, 2015.

\begin{tabular}{|c|c|c|c|c|c|c|}
\hline \multirow{3}{*}{$\begin{array}{l}\text { Treatments } \\
\text { Assay } 1 \\
\text { Negative control }\end{array}$} & \multicolumn{3}{|c|}{$5 \%$} & \multicolumn{3}{|c|}{$50 \%$} \\
\hline & \multicolumn{2}{|c|}{ CFU plate ${ }^{-1}$} & \multirow{2}{*}{$\begin{array}{c}\text { \% inhibition } \\
-\end{array}$} & \multicolumn{2}{|c|}{ CFU plate ${ }^{-1}$} & \multirow{2}{*}{$\begin{array}{c}\text { \% inhibition } \\
-\end{array}$} \\
\hline & 201 & $\mathrm{Aa}^{1}$ & & 201 & $\mathrm{Aa}$ & \\
\hline Memnoniella levispora & 187 & $\mathrm{Ab}$ & 7.0 & 154 & $\mathrm{Bb}$ & 23.4 \\
\hline Periconia hispidula & 198 & $\mathrm{Aa}$ & 1.5 & 164 & $\mathrm{Bb}$ & 18.4 \\
\hline Zygosporium echinosporum & 157 & $\mathrm{Bc}$ & 21.9 & 103 & $\mathrm{Bc}$ & 48.8 \\
\hline Chloridium virescens var. virescens & 143 & $\mathrm{Bc}$ & 28.9 & 98 & $\mathrm{Bc}$ & 51.2 \\
\hline C.V. $(\%)$ & \multicolumn{3}{|c|}{3.7} & \multicolumn{3}{|c|}{4.1} \\
\hline \multicolumn{7}{|l|}{ Assay 2} \\
\hline Negative control & 212 & $\mathrm{Aa}$ & - & 212 & $\mathrm{Aa}$ & - \\
\hline Memnoniella levispora & 198 & Aa & 6.6 & 162 & $\mathrm{Bb}$ & 23.6 \\
\hline Periconia hispidula & 200 & $\mathrm{Aa}$ & 5.7 & 178 & $\mathrm{Bb}$ & 16.0 \\
\hline Zygosporium echinosporum & 178 & $\mathrm{Ab}$ & 16.0 & 102 & $\mathrm{Bc}$ & 51.9 \\
\hline Chloridium virescens var. virescens & 153 & $\mathrm{Ac}$ & 27.8 & 98 & $\mathrm{Bc}$ & 53.8 \\
\hline C.V. $(\%)$ & \multicolumn{3}{|c|}{5.6} & \multicolumn{3}{|c|}{5.3} \\
\hline
\end{tabular}

${ }^{1}$ Mean values followed by the same lowercase letters vertically and capital letters horizontally are not significantly different from each other according to Tukey's test at 5\% probability.

All the treatments produced significant bacterial growth inhibition in comparison to the negative control upon the addition of the filtrates to the culture medium at the $50 \%(\mathrm{v} / \mathrm{v})$. The bacterial growth inhibitory effects of $M$. levispora (23.4 to $23.6 \%$ ) and $P$. hispidula (16.0 to $18.4 \%$ ) did not significantly differ from each other. The bacterial growth inhibitory effects of $Z$. echinosporum (48.8 to $51.9 \%$ ) and $C$. virescens var. virescens $(51.25$ to $53.8 \%$ ) were significantly greater than those of the other isolates. Significant difference was observed between the tested concentrations of the fungal filtrates (Table 2); notably, bacterial growth inhibition was higher at $50 \%$ than at $5 \%$.
Other authors have observed that saprobe fungi have antagonistic and fungitoxic effects on some other fungi. Silva et al. (2008) evaluated the in vitro antagonistic activity of Trichoderma spp. on Phytophthora citrophthora using the paired culture method. Those authors found that T. stromaticum had the highest antagonistic effect. Balbi-Peña et al. (2012) and Barros et al. (2015) studied in vitro antagonistic effect of saprobe fungi S. globosa and M. levispora on Sclerotinia sclerotiorum. Also, $C$. virescens var. virescens had an in vitro inhibitory effect on the mycelial growth of Colletotrichum gloeosporioides, the causal agent of anthracnose of guava trees, which was associated with competition for space, nutrients, and/or antiobiosis (ALVES, 
2013). According to Sid Ahmed et al. (2003) the presence of diffusible antifungal metabolites in the culture medium inhibits mycelial growth by promoting cell disruption and causing the lysis of hyphae.

The incubation of $X$. euvesicatoria with saprobe fungi colonies in 2-sections divided dishes indicated that only $C$. virescens var. virescens produced volatile compounds capable of reducing the number of bacterial CFUs ( $25 \%$ ) (Table 3 ). Volatile compounds produced by $P$. hispidula and $Z$. echinosporum led to an increase in the number of bacterial CFUs per plate relative to the negative control. Volatile compounds of M. levispora did not alter the number of $X$. euvesicatoria colonies.

Table 3. Effects of volatile compounds of saprobe fungi on the colony-forming units (CFUs per plate) of Xanthomonas euvesicatoria. Londrina, 2015.

\begin{tabular}{|c|c|c|c|}
\hline Treatments & \multirow{2}{*}{\multicolumn{2}{|c|}{ CFU plate ${ }^{-1}$}} & \multirow{2}{*}{$\%$ inhibition } \\
\hline Assay 1 & & & \\
\hline Negative control & 245 & $\mathrm{~b}^{1}$ & ---- \\
\hline Memnoniella levispora & 266 & $\mathrm{~b}$ & -8.6 \\
\hline Periconia hispidula & 385.6 & $\mathrm{a}$ & -57.4 \\
\hline Zygosporium echinosporum & 299.6 & $\mathrm{a}$ & -22.3 \\
\hline Chloridium virescens var. virescens & 185.2 & $\mathrm{c}$ & 24.4 \\
\hline C.V. $(\%)$ & \multicolumn{3}{|c|}{3.7} \\
\hline \multicolumn{4}{|l|}{ Assay 2} \\
\hline Negative control & 283 & $\mathrm{~b}$ & ---- \\
\hline Memnoniella levispora & 299 & $\mathrm{~b}$ & -22.0 \\
\hline Periconia hispidula & 401.3 & $\mathrm{a}$ & -63.8 \\
\hline Zygosporium echinosporum & 399.6 & $\mathrm{a}$ & -63.1 \\
\hline Chloridium virescens var. virescens & 181.6 & $\mathrm{c}$ & 25.9 \\
\hline C.V. $(\%)$ & \multicolumn{3}{|c|}{4.2} \\
\hline
\end{tabular}

${ }^{1}$ Mean values followed by the same letter in the column are not significantly different according to Tukey's test at 5\% probability.

Volatile organic compounds are low-molecularweight molecules. Because they are gaseous compounds, their diffusion into biological plasma membranes is favored, and they may represent a good strategy for phytopathogen control (DUDAREVA et al., 2006). The fungus Muscodor albus produces volatile organic compounds (alcohols, esters, ketones, acids, and lipids) that inhibit phytopathogenic fungi and bacteria (STROBEL et al., 2001). Similarly, Muscodor crispans produces organic compounds capable of inhibiting certain phytopathogens in vitro, including Xanthomonas citri subsp. citri, the causal agent of citrus canker (MITCHELL et al., 2010).
In the present study, the preventive treatment in the greenhouse tomato plants with the four selected saprobe fungi filtrates (Table 4) reduced AUDPC by approximately $70 \%$ in both assays (not significantly different from ASM) seven days after inoculation (DAI). Treatments with the four selected saprobe fungi filtrates and ASM in the second assay reduced the disease severity compared with the negative control. Plants treated with Z. echinosporum with $7 \%$ of the leaf area affected by bacterial spot were statistically different from plants treated with $P$. hispidula with $3 \%$ of the leaf area affected but neither of these fungal treatments was different from the positive control (ASM; Table 4). 
Table 4. Severity (percentage of affected leaf area) and area under disease progress curve (AUDPC) of bacterial spot of tomato plants at 7,14, and 21 days after inoculation (DAI) with Xanthomonas euvesicatoria in plants previously treated with saprobe fungi filtrates. Londrina, 2015.

\begin{tabular}{|c|c|c|c|c|c|}
\hline \multirow{2}{*}{$\begin{array}{l}\text { Treatments } \\
\text { Assay } 1\end{array}$} & \multicolumn{3}{|c|}{ Affected leaf area $(\%)$} & \multirow{2}{*}{ AUDPC } & \multirow{2}{*}{$\begin{array}{c}\text { \% reduction } \\
\text { AUDPC }\end{array}$} \\
\hline & 7 DAI & 14 DAI & 21 DAI & & \\
\hline Negative control & $15.0 \mathrm{a}^{1}$ & $23.0 \mathrm{a}$ & $52.0 \mathrm{a}$ & $22.1 \mathrm{a}$ & \\
\hline Positive control (ASM) $)^{2}$ & $5.0 \mathrm{~b}$ & $12.0 \mathrm{~b}$ & $14.0 \mathrm{~b}$ & $8.3 \mathrm{~b}$ & 62.4 \\
\hline Periconia hispidula & $5.0 \mathrm{~b}$ & $7.0 \mathrm{~b}$ & $20.0 \mathrm{~b}$ & $7.6 \mathrm{~b}$ & 65.6 \\
\hline Zygosporium echinosporum & $5.0 \mathrm{~b}$ & $6.0 \mathrm{c}$ & $21.0 \mathrm{~b}$ & $7.4 \mathrm{~b}$ & 66.5 \\
\hline Chloridium virescens var. virescens & $5.0 \mathrm{~b}$ & $8.0 \mathrm{~b}$ & $15.0 \mathrm{~b}$ & $7.2 \mathrm{~b}$ & 67.4 \\
\hline Memnoniella levispora & $5.0 \mathrm{~b}$ & $8.0 \mathrm{~b}$ & $13.0 \mathrm{c}$ & $6.7 \mathrm{~b}$ & 69.9 \\
\hline C.V. $(\%)$ & 40.3 & 19.8 & 13.6 & 11.8 & \\
\hline \multicolumn{6}{|l|}{ Assay 2} \\
\hline Negative control & $15.0 \mathrm{a}$ & $23.0 \mathrm{a}$ & $54 \mathrm{a}$ & $23.4 \mathrm{a}$ & \\
\hline Positive control (ASM) & $5.0 \mathrm{bc}$ & $12.0 \mathrm{~b}$ & $14.0 \mathrm{~d}$ & $8.2 \mathrm{~b}$ & 64.9 \\
\hline Periconia hispidula & $3.0 \mathrm{c}$ & $7.0 \mathrm{~b}$ & $20.0 \mathrm{bc}$ & $7.5 \mathrm{~b}$ & 67.9 \\
\hline Zygosporium echinosporum & $7.0 \mathrm{~b}$ & $7.0 \mathrm{~b}$ & $21.0 \mathrm{~b}$ & $7.4 \mathrm{~b}$ & 68.3 \\
\hline Chloridium virescens var. virescens & $5.0 \mathrm{bc}$ & $8.0 \mathrm{~b}$ & $15.0 \mathrm{~cd}$ & $7.1 \mathrm{~b}$ & 69.6 \\
\hline Memnoniella levispora & $5.0 \mathrm{bc}$ & $8.0 \mathrm{~b}$ & $13.0 \mathrm{~d}$ & $6.7 \mathrm{~b}$ & 71.3 \\
\hline C.V. $(\%)$ & 41.3 & 22.0 & 15.8 & 10.9 & \\
\hline
\end{tabular}

At the second evaluation (14 DAI) of the first assay all the treatments with the fungal filtrates and ASM reduced bacterial spot severity. Treatment with $Z$. echinosporum resulted in a significantly smaller affected leaf area than ASM, demonstrating higher disease control. In the second assay, all the treatments also reduced bacterial spot severity but there were no significant differences between control efficacies of the fungal filtrates and ASM.

In the third evaluation (21 DAI), all the treatments with the four fungal filtrates and ASM again reduced disease severity. The treatment with $M$. levispora in the first assay resulted in a significantly smaller affected leaf area compared to the other fungal isolates and the ASM positive control. In the second assay, all the saprobe filtrates and ASM significantly controlled the disease, with the M. levispora, ASM, and $C$. virescens var. virescens treatments resulting in the lowest affected leaf areas $(13 \%, 14 \%$, and $15 \%$, respectively).
With respect to the AUDPC, both assays showed that all the treatments with saprobe fungi filtrates provided efficient control of bacterial spot in tomato plants, similar to that of ASM.

According to Pernezny et al. (2012), the most promising biological control agents for bacterial spot of tomato are bacteriophages specific for $X$. vesicatoria, which should be applied preventively. Other biocontrol agents and methods, such the application to the phylloplane of Cellulomonas turbata, Pseudomonas syringae, Pseudomonas putida, hrp (hypersensitive response and pathogenicity) mutant isolates of $X$. campestris pv. vesicatoria, Rahnella aquatilis, or Bacillus subtilis (BYRNE et al., 2005; MOSS et al., 2007; EL-HENDAWY et al., 2005; ROBERTS et al., 2008), have been previously tested for the control of bacterial spot. However, studies on the effects of fungal metabolites on plant bacteria control are scarce in the literature. Botrel (2013) tested saprobe 
fungi cultures for the control of coffee tree spot (caused by Pseudomonas syringae pv. garcae) in Brazil. That author found that the fungus $M$. levispora reduced the severity of the disease in curative applications, showing the same AUDPC values as the ASM positive control. M. levispora also induced rooting of eucalyptus cuttings and inhibited the germination of urediniospores of Puccinia psidii (PIEROZZI, 2013).

Table 5. Severity (percentage of affected leaf area) and area under disease progress curve (AUDPC) of bacterial spot of tomato plants on their third and fourth leaves at 7, 14, and 21 days after inoculation (DAI) with Xanthomonas euvesicatoria in plants previously treated with saprobe fungi filtrates only on the third leaf. Londrina, 2015.

\begin{tabular}{|c|c|c|c|c|}
\hline \multirow{3}{*}{ Treatments } & \multicolumn{4}{|c|}{$3^{\text {rd }}$ Leaf } \\
\hline & \multicolumn{3}{|c|}{ Affected leaf area $(\%)$} & \multirow{2}{*}{ AUDPC } \\
\hline & 7 DAI & 14 DAI & 21 DAI & \\
\hline Negative control & $15.0 \mathrm{a}^{1}$ & $23.0 \mathrm{a}$ & $52.0 \mathrm{a}$ & $22.1 \mathrm{a}$ \\
\hline Positive control (ASM) ${ }^{2}$ & $5.0 \mathrm{~b}$ & $12.0 \mathrm{~b}$ & $14.0 \mathrm{~b}$ & $8.3 \mathrm{~b}$ \\
\hline Periconia hispidula & $5.0 \mathrm{~b}$ & $7.0 \mathrm{~b}$ & $20.0 \mathrm{~b}$ & $7.6 \mathrm{~b}$ \\
\hline Zygosporium echinosporum & $5.0 \mathrm{~b}$ & $6.0 \mathrm{c}$ & $21.0 \mathrm{~b}$ & $7.4 \mathrm{~b}$ \\
\hline Chloridium virescens var. virescens & $5.0 \mathrm{~b}$ & $8.0 \mathrm{~b}$ & $15.0 \mathrm{~b}$ & $7.2 \mathrm{~b}$ \\
\hline Memnoniella levispora & $5.0 \mathrm{~b}$ & $8.0 \mathrm{~b}$ & $13.0 \mathrm{c}$ & $6.7 \mathrm{~b}$ \\
\hline \multirow[t]{2}{*}{ C.V. $(\%)$} & 40.3 & 19.8 & 13.6 & 11.8 \\
\hline & & & $4^{\text {th }}$ Leaf & \\
\hline Negative control & $15.0 \mathrm{a}$ & $25.0 \mathrm{a}$ & $58.0 \mathrm{a}$ & $21.3 \mathrm{a}$ \\
\hline Positive control (ASM) & $5.0 \mathrm{c}$ & $12.0 \mathrm{~b}$ & $14.0 \mathrm{~d}$ & $8.1 \mathrm{~b}$ \\
\hline Periconia hispidula & $5.0 \mathrm{c}$ & $7.0 \mathrm{~b}$ & $20.0 \mathrm{~cd}$ & $7.3 \mathrm{~b}$ \\
\hline Zygosporium echinosporum & $5.0 \mathrm{c}$ & $6.0 \mathrm{~b}$ & $21.0 \mathrm{c}$ & $7.1 \mathrm{~b}$ \\
\hline Chloridium virescens var. virescens & $10.0 \mathrm{~b}$ & $20.0 \mathrm{a}$ & $50.0 \mathrm{~b}$ & $18.3 \mathrm{a}$ \\
\hline Memnoniella levispora & $4.8 \mathrm{c}$ & $6.0 \mathrm{~b}$ & $12.0 \mathrm{~d}$ & $6.9 \mathrm{~b}$ \\
\hline C.V. $(\%)$ & 24.5 & 23.1 & 8.9 & 11.7 \\
\hline
\end{tabular}

${ }^{1}$ Mean values followed by the same letter in a column are not significantly different according to Tukey's test at $5 \%$ probability.

${ }^{2}$ Acibenzolar- $S$-methyl.

The assay intended to verify systemicity of the control of bacterial spot by the saprobe fungi filtrates revealed that all the treatments with the four selected saprobe filtrates and ASM presented a lower disease severity in the third leaf (7 DAI) than the negative control did (Table 5). As for the fourth leaf, it was found that the filtrates of $P$. hispidula, Z. echinosporum, M. levispora, as well as the ASM positive control, all presented a lower affected leaf area $(\sim 5 \%)$ than the negative control did. In addition, all the treatments resulted in lower disease severity than the negative control did in the third leaf at 14 DAI. The treatment with Z. echinosporum filtrates resulted in a significantly smaller affected leaf area than the ASM positive control did. Except for the $C$. virescens var. virescens treatment, all treatments resulted in a lower disease severity in the fourth leaf. At 21 DAI, all the treatments exerted significant bacterial control in the third leaf; in particular, the treatment with $M$. levispora showed a significantly higher control efficacy than the other treatments. Lower percentages of diseased area on the fourth leaf were observed after treatment with the filtrates of $P$. hispidula, M. levispora, and ASM in comparison to the negative control.

With respect to the AUDPC for the third leaf, all the treatments significantly controlled bacterial spot compared with the negative control, without significant differences with ASM. As for the fourth leaf, treatment with $C$. virescens var. virescens did 
not show significant bacterial control compared to the negative control, while the other treatments with fungal filtrates reduced disease severity. These results indicate that the preventive treatment of tomato plants with the filtrates of $Z$. echinosporum, M. levispora, or P. hispidula, or with ASM, induced a systemic control of tomato bacterial spot and the filtrate of $C$. virescens var. virescens exerted a localized disease control.

\section{Conclusions}

The selected saprobe fungi (Periconia hispidula, Zygosporium echinosporum, Chloridium virescens var. virescens, and Memnoniella levispora) showed potential for the biological control of bacterial spot of tomato. This study revealed that these fungi produce nonvolatile compounds (all the fungi selected) and volatile ones (in the case of $C$. virescens var. virescens) that are toxic towards $X$. euvesicatoria. Although the activity of defense-related enzymes and other plant defense responses were not evaluated, systemicity of tomato bacterial spot control by preventive treatment with $P$. hispidula, $Z$. echinosporum, and $M$. levispora filtrates was verified, suggesting a possible induction of resistance to bacterial spot by compounds produced by these fungi. Biochemical and molecular defense responses of the plant should be addressed in future studies to elucidate the disease control mechanism of these saprobe fungi.

\section{Acknowledgments}

The authors acknowledge the Coordination for the Improvement of Higher Education Personnel (CAPES) for the research scholarship to D.C. Peitl.

\section{References}

AL-DAHMANI, J. H.; ABBASI, P. A.; MILLER, S. A.; HOITINK, H. A. J. Suppression of bacterial spot of tomato with foliar sprays of compost extracts under greenhouse and field conditions. Plant Disease, Saint Paul, v. 87, n. 8, p. 913-919, 2003.

ALVES, F. M. F. R. Avaliação de fungos sapróbios no controle pós-colheita da antracnose em goiabeiras Pedro Sato. 2013. Dissertação (Mestrado em Agricultura Tropical e Subtropical) - Instituto Agronômico, Campinas.

ARAÚJO, E. R.; COSTA, J. R.; FERREIRA, M. A. S. V.; QUEZADO-DUVAL, A. M. Widespread distribution of Xanthomonas perforans and limited presence of $X$. gardneri in Brazil. Plant Pathology, Oxford, v. 66, n. 1, p. 159-168, 2017.

AREAS, M. S.; GONÇALVES, R. M.; SOMAN, J. M.; SAKATE, R. K.; GIORIA, R.; SILVA JÚNIOR, T. A. F.; MARINGONI, A. C. Prevalence of Xanthomonas euvesicatoria on pepper in Brazil. Journal of Phytopathology, Berlin, v. 163, n. 11-12, p. 1050-1054, 2015.

BALBI-PEÑA, M. I.; MELLO, F. E.; PEITL, D. C.; CALVO, N. S.; ARAUJO, F. A.; SUMIDA, C. H. Teste de confrontação direta entre fungos sapróbios $e$ Sclerotinia sclerotiorum em diferentes meios de cultura. In: Congresso Brasileiro de Fitopatologia, 45. Manaus, AM. Tropical Plant Pathology, Brasília v. 37, p. 476, ago. 2012. Suplemento. Disponível em: $<$ http://www.sbfito. com.br/tpp/Suplemento_2012_ Manaus.pdf $>$. Acessed at: 16 jun. 2016.

BARROS, D. C. M.; FONSECA, I. C. B.; BALBI-PEÑA, M. I.; PASCHOLATI, S. F.; PEITL, D. C. Biocontrol of Sclerotinia sclerotiorum and white mold of soybean using saprobic fungi from semi-arid areas of Northeastern Brazil. Summa Phytopathologica, Botucatu, v. 41, n. 4, p. 251-255, 2015.

BOTREL, D. A. Fungos sapróbios como agentes de biocontrole da mancha aureolada (Pseudomonas syringae pv. garcea) no cafeeiro. 2013. Dissertação (Mestrado em Agronomia) - Universidade Federal de Lavras, Lavras, MG.

BYRNE, J. M.; DIANESE, A. C.; JI, P.; CAMPBELL, H. L.; CUPPELS, D. A.; LOUWS, F. J.; MILLER, S. A.; JONES, J. B.; WILSON, M. Biological control of bacterial spot of tomato under field conditions at several locations in North America. Biological Control, Orlando, v. 32, n. 3, p. 408-418, 2005. 
DELlAPORTA, S. L.; WOOD, J.; HICKS, J. B. A plant DNA minipreparation: version II. Plant Molecular Biology Reporter, Athens, v. 1, n. 4, p. 19-21, 1983.

DUDAREVA, N.; NEGRE, F.; NAGEGOWDA, D. A.; ORLOVA, I. Plant volatiles: recent advanced and future perspectives. Critical Reviews in Plant Science, Boca Raton, v. 25, n. 5, p. 417-440, 2006.

EL-HENDAWY, H. H.; OSMAN, M. E.; SOROUR, N. M. Biological control of bacterial spot of tomato caused by Xanthomonas campestris pv. vesicatoria by Rahnella aqualis. Microbiological Research, Jena, v. 160, n. 4, p. 343-352, 2005.

FERRAZ, H. G. M.; RESENDE, R. S.; MOREIRA, P. C.; SILVEIRA, P. R.; MILAGRES, E. A.; OLIVEIRA, J. R.; RODRIGUES, F. A. Antagonistic rhizobacteria and jasmonic acid induce resistance against tomato bacterial spot. Bragantia, Campinas, v. 74, n. 4, p. 417-427, 2015.

FLAHERTY, J. E.; SOMODI, G. C.; JONES, J. B.; HARBAUGH, B. K.; JACKSON, L. E. Control of bacterial spot on tomato in the greenhouse and field with h-mutant bacteriophages. HortScience, Alexandria, v. 35, n. 5 , p. $882-884,2000$.

FOOD AND AGRICULTURE ORGANIZATION OF THE UNITED NATIONS - FAO. FAOSTAT, Food and Agricultural commodities production. Rome, 2016. Available at: <http://faostat3.fao.org/browse/ Q/QC/E>. Acessed at: 17 jun. 2016.

FRY, W. E. Quantification of general resistance of potato cultivars and fungicide effects for integrated control of potato late blight. Phytopathology, Saint Paul, v. 68, n. 11, p. 1650-1655, 1978.

INSTITUTO BRASILEIRO DE GEOGRAFIA E ESTATÍSTICA - IBGE. Produção agrícola municipal. Rio de Janeiro: IBGE, 2013. Disponível em: <http:// www.ibge.gov.br>. Acessed at: 10 jun. 2016.

JONES, J. B.; LACY, G. H.; BOUZAR, H.; STALL, R. E.; SCHAAD, N. W. Reclassification of the Xanthomonads associated with bacterial spot disease of tomato and pepper. Systematic and Applied Microbiology, Stuttgart, v. 27, n. 6, p. 755-762, 2004.

JONES, J. B.; STALL, R. E.; BOUZAR, H. Diversity among xanthomonads pathogenic on pepper and tomato. Annual Review of Phytopathology, Palo Alto, v. 36, n. 1, p. 41-58, 1998.

KESSMANN, H.; STAUB, T.; HOFMANN, C.; MAETZKE, T.; HERZOG, J.; WARD, E.; UKNES, S.; RYALS, J. Induction of systemic acquired disease resistance in plants by chemicals. Annual Review of Phytopathology, Stanford, v. 32, n. 1, p. 439-459, 1994.
KOENRAADT, H.; VAN BETTERAY, B.; GERMAIN, R.; HIDDINK, G.; JONES, J. B.; OOSTERHOF, J. Development of specific primers for the molecular detection of bacterial spot of pepper and tomato. Acta Horticulturae, The Hague, v. 808, n. 13, p. 99-102, 2007.

LANNA-FILHO, R.; SOUZA, R. M.; MAGALHÃES, M. M.; VILLELA, L.; ZANOTTO, E.; RIBEIRO-JÚNIOR, P. M.; RESENDE, M. L. Induced defense responses in tomato against bacterial spot by proteins synthesized by endophytic bacteria. Tropical Plant Pathology, Brasília, v. 38, n. 4, p. 295-302, 2013.

LOPES, C. A.; ÁVILA, A. C. Doenças do tomate. Brasília: EMBRAPA Hortaliças, 2005. 151 p.

MARTIN, H. L.; HAMILTON, V. A.; KOPITTKE, R. A. Copper tolerance in Australian populations of Xanthomonas campestris pv. vesicatoria contributes to poor field control of bacterial spot of pepper. Plant Disease, Saint Paul, v. 88, n. 9, p. 921-924, 2004.

MELlO, S. C.; TAKATSU, A.; LOPES, C. A. Escala diagramática para avaliação da mancha-bacteriana do tomateiro. Fitopatologia Brasileira, Brasília, v. 22, n. 3, p. 447-449, 1997.

MITCHELL, A. M.; STROBEL, G. A.; MOORE, E.; ROBISON, R.; SEARS, J. Volatile antimicrobials from Muscodor crispans, a novel endophytic fungus. Microbiology, New York, v. 156, n. 1, p. 270-277, 2010.

MOSS, W. P.; BYRNE, J. M.; CAMPBELL, H. L.; JI, P.; BONAS, U.; JONES, J. B.; WILSON, M. Biological control of bacterial spot of tomato using hrp mutants of Xanthomonas campestris pv. vesicatoria. Biological Control, Orlando, v. 41, n. 2, p. 199-206, 2007.

OBRADOVIC, A.; JONES, J. B.; MOMOL, M. T.; BALOGH, B.; OLSON, S. M. Management of tomato bacterial spot in the field by foliar applications of bacteriophages and SAR inducers. Plant Disease, Saint Paul, v. 88, n. 7, p. 736-740, 2004.

OBRADOVIC, A.; JONES, J. B.; MOMOL, M. T.; OLSON, S. M.; JACKSON, L. E.; BALOGH, B.; GUVEN, K.; IRIARTE, F. B. Integration of biological control agents and systemic acquired resistance inducers against bacterial spot on tomato. Plant Disease, Saint Paul, v. 89, n. 7, p. 712-716, 2005.

PERNEZNY, K.; DAVIS, R. M.; MOMOL, T. Management of important bacterial diseases. In: DAVIS, R. M.; PERNEZNY, K. L.; BROOME, J. C. (Ed.). Tomato health management. Saint Paul: American Phytopathological Society, 2012. chapter 11, p. 102-112. 
PIEROZZI, C. G. Fungos sapróbios do semiárido nordestino: aspectos fisiológicos, ação no controle da ferrugem e indução de enraizamento em mudas de eucalipto. 2013. Dissertação (Mestrado em Ciência Florestal) - Universidade Estadual Paulista Júlio de Mesquita, Botucatu.

PINTO, F. A. M. F. Controle da mancha manteigosa com fungos sapróbios em cefeeiro. 2013. Dissertação (Mestrado em Fitopatologia) - Universidade Federal de Lavras, Lavras.

RESENDE, R. S.; MILAGRES, C. A.; REZENDE, D.; AUCIQUE-PEREZ, C. E.; RODRIGUES, F. Á. Bioprospecting of saprobe fungi from the semi-arid north-east of Brazil for the control of anthracnose on sorghum. Journal of Phytopathology, Berlin, v. 163, n. 10, p. 787-794, 2015.

RITCHIE, D. F. Bacterial spot of pepper and tomato. The plant health instructor. Saint Paul: The American Phytopathological Society, 2007. Available at: <http:// www.apsnet.org/edcenter/intropp/lessons/ prokaryotes/ Pages/Bacterialspot.aspx>. Acessed at: 10 jun. 2016.

ROBERTS, P. D.; MOMOL, M. T.; RITCHIE, L.; OLSON, S. M.; JONES, J. B.; BALOGH, B. Evaluation of spray programs containing famoxadone plus cymoxanil, acibenzolar-S-methyl, and Bacillus subtilis compared to copper sprays for management of bacterial spot on tomato. Crop Protection, Guildford, v. 27, n. 12, p. 1519-1526, 2008.

ROMERO, A. M.; KOUSIK, C. S.; RITCHIE, D. F. Resistance to bacterial spot in bell pepper induced by acibenzolar-S-methyl. Plant Disease, Saint Paul, v. 85, n. 2, p. 189-194, 2001.

SHANER, G.; FINNEY, R. E. The effect of nitrogen fertilization on the expression of slow-mildewing resistance in knox wheat. Phytopathology, Saint Paul, v. 67, n. 8, p. 1051-1056, 1977.
SID AHMED, A.; EZZIYYANI, M.; SÁNCHEZ, C. P.; CANDELA, M. E. Effect of chitin on biological control activity of Bacillus spp. and Trichoderma harzianum against root rot disease in pepper (Capsicum annuum) plants. European Journal of Plant Pathology, Dordrecht, v. 109, n. 6, p. 633-637, 2003.

SILVA, K. S.; REBOUÇAS, T. N. H.; BOMFIM, M. P.; SILVA, D. S.; SÃO JOSÉ, A. R.; BENETT, C. G. S. Atividade antagônica in vitro de isolados de Trichoderma spp. ao fungo Phytophthora citrophthora. Semina: Ciências Agrárias, Londrina, v. 29, n. 4, p. 749-754, 2008.

STALL, R. E.; LOSCHKE, D. C.; JONES, J. B. Linkage of copper resistance and avirulence loci on a selftransmissible plasmid in Xanthomonas campestris pv. vesicatoria. Phytopathology, Saint Paul, v. 76, n. 2, p. 240-243, 1986.

STROBEL, G. A.; DIRKSE, E.; SEARS, J.; MARKWORTH, C. Volatile antimicrobials from Muscodor albus, a novel endophytic fungus. Microbiology, Reading, v. 147, n. 11, p. 2943-2950, 2001.

WIGHTWICK, A.; WALTERS, R.; ALLINSON, G.; REICHMAN, S. M.; MENZIES, N. W. Environmental risks of fungicides used in horticultural production systems. In: CARISSE, O. (Ed.). Fungicides. Reijka: InTech, 2010. p. 273-304.

YEDIDIA, I.; SHORESH, M.; KEREM, Z.; BENHAMOU, N.; KAPULNIK, Y.; CHET, I. Concomitant induction of systemic resistance to Pseudomonas syringae pv. lachrymans in cucumber by Trichoderma asperellum (T-203) and the accumulation of phytoalexins. Applied and Environmental Microbiology, Washington, v. 69, n. 12, p. 7343-7353, 2003. 
